\title{
Recovering the astonishment: In palliative care, medicine, and life
}

Miguel Julião, M.D., M.SC., PH.D. ${ }^{1}$ (D), Matías Najún, M.D. ${ }^{2}$ and Ana Bragança, M.D. ${ }^{3}$

\section{Essay/Personal Reflection}

Cite this article: Julião $M$, Najún $M$, Bragança A (2021). Recovering the astonishment: In palliative care, medicine, and life. Palliative and Supportive Care 19, 380-381. https:// doi.org/10.1017/S147895152000036X

Received: 4 March 2020 Revised: 27 March 2020 Accepted: 18 May 2020

Author for correspondence: Miguel Julião, Equipa Comunitária de Suporte em Cuidados Paliativos de Sintra, Sintra, Portugal. E-mail: migueljuliao@gmail.com Central, Lisboa, Portugal

When did we forget to stare at the world, all its nuances, and become astonished? When did this fade away? Yesterday? Everyday? Forever? within us. and become previously alert to every encounter to happen...

When we travel...
${ }^{1}$ Equipa Comunitária de Suporte em Cuidados Paliativos de Sintra, Sintra, Portugal; ${ }^{2}$ Austral University Hospital and Good Samaritan Hospice, Pilar, Buenos Aires, Argentina and ${ }^{3}$ Agrupamento de Centros de Saúde de Lisboa

No. Not always, although very often. We are still able to echo with the world outside and

For instance, when we travel. Traveling excitement places us before novelty, drives us to look for new experiences, new people, cultures, and colors. Before traveling, we read about the newness to come, we learn some words to connect with strangers, we research the customs

Another example is art, in many of its shapes. Let us take painting, for example. When we sit in front of an outstanding painting, resting on a bench in some famous museum. We let ourselves emerge in the beauty, the light, the colors, and the orientation of the brush strokes. We contemplate in silence and ask ourselves about the painter: "Who is he?," "How much hours did he spend painting this piece of art?," "What is his life story, his passions, miseries, and glories?"; and we regret not having the person face to face to discover more deeply his heart and mind, his thoughts and feelings when he painted...

When we see a beautiful painting...

There was a time when we all knew how to live in amazement. Our childhood had moments in which every instant was crucial, subtle and unique. True milestones. "I discovered something and I want you to see it too!"; “I'm amazed!” Back then, the world was something to venture, to discover, to share, and to know more about. An attitude that may be numb and that for many have faded away through life, even when surrounded by so much mystery and possible encounters.

When we were young...

This is a shared personal reflection: three individuals, palliative care physicians, three visions, and a common feeling about the need for introspection, writing, and recovery of the misplaced astonishment in everyday life and especially in the core of medicine.

As this article is written in English, we will anchor on the word astonishment or use others like amazement, admiration, and surprise; but as the authors are Portuguese and Latin American, it is but fair to also present to readers the beauty of its many synonymous in our languages: espanto, assombro/asombro, admiração/admiración, and surpresa/sorpresa.

Espanto derives from the Latin expaventare, which describes the strong impression caused by something unexpected and sudden (Mendonça, 2019). Astonishment is not static, nor unilateral. When amazed, we are invited to a conscious, blazing, unarmed, surrendered, and non-predetermined contact, with a life that is bigger than us (Mendonça, 2019), inviting to the discovery of the uniqueness of moments, persons, and stories. It is an invitation to be predisposed, open, willing to be touched by someone, by something, or by nothing at all. Perhaps, this is one of the most unsettling decisions to make: the one of being unarmed and unburied, predisposed, humble, and permeable to astonishment.

Expaventare is a double-sided coin "flipping" in many of our daily encounters with healthy people and with those with terminal conditions. Amazement brings us knowledge (and the "thirst" for it), the marvel and excitement, but also the fear and anguish before the unknown. Amazement needs time for contemplation, silence, and openness, but modern life invites for the immediacy of stances and opinions. Therefore, astonishment requires predisposition and learning, the creation of a new and permanent space within ourselves to surprise us, guided by continuous discernment and consequent action. An awareness attitude towards other disrupts individuals, creating a state of alertness and internal tension. Astonishment dismantles us piece-by-piece - like with a piece of porcelain that breaks - leaving breaches where existential interchanges can flood. When this happens, through being knowledgeable of others, we grow as persons and physicians.

Palliative care values are anchored in finding the profound and latent aspects of patients lives beyond their life-limiting conditions, recovering personhood from the shadows of patienthood, vulnerability, illnesses, and social disappearance. To do so, palliative care professionals - 
and medicine itself as a whole - have to reclaim and relearn the importance of admiration and surprise, being diligent in the exercise of astonishment and amazement in each clinical encounter. Probably, the true intangible definition of palliative care rests here. Although challenging, this effort will be one of the cornerstones to delivering a different culture of medicine, bringing to surface one of the most precious goals of medicine: to care for others genuinely. Nowadays, there are many barriers and difficulties to the practice of astonishment in palliative care. Acknowledging the factors that draw us away from people's cores helps us understand how to return to the essential pathway. Lack of time, task burden, little space for individual or collective reflection, emotional numbness facing suffering, or even the blindness for palliative care technical aspects, apart us from each day, surprises when caring for people, «as it seems that we have seen everything, we experienced and knew everything, and we look at reality protected by what we think is a safe distance» (Mendonça, 2018). This lack of sensitivity to astonishment removes us from the curiosity state of what lies before our eyes, becoming just mere lethargic witnesses of others' glimpses. It is as if we are on autopilot.

In the exercise of medicine and palliative care, astonishment teaches us the profound respect for each life, revealing «man based on his dignity and unique and unrepeatable aspects, from the moment of his conception until his death» (Sgreccia, 2009). Patients with whom we come across have the right to tell us their stories, far beyond their terminal conditions and during their treatments; and expaventare is the unique opportunity for health professionals to capture moments and bequeath their life stories.
The truest palliative care specialist's curriculum vitae is a lifetime "collection" of haunts, silent words, glances, impressions, and life stories, i.e., a chest full of amazement.

There is no room for passive amazement, nor is surprise a frozen concept.

It is time to return to the amazement of astonishment, as a first encounter with the primordial and intangible reality of life. Palliative care professionals are invited to become more than talented technicians; they are expected to become beholders also, relearning to be amazed, surprised, and open to the presence of people in suffering. Astonishment is not an ex nihilo task as we have always been connected; we just have to regain openness and alertness again towards each other's.

Can we still travel within our patients' lives?

Can we still paint the last portrait of our patients' lives?

Can we still be amazed like when we were young?

We are capable of returning to all of those, and that is astonishment, and it must return to the core of medicine, palliative care, and our lives.

\section{References}

Mendonça JT (2018) Aprendizes do Espanto. In Elogio da Sede. Lisboa: Quetzal Editores, pp. 14.

Mendonça JT (2019) Beleza. In Uma Beleza que nos Pertence. Lisboa: Quetzal Editores, pp. 95.

Sgreccia E (2009) Capítulo Quarto. A pessoa humana e o seu corpo. In Manual de Bioética - Fundamentos e Ética Biomédica. Cascais: Princípia Editora Lda, pp. 136. 